\title{
PERLUKAH REFORMASI SEKTOR INTELIJEN DI TUBUH PERTAHANAN INDONESIA?
}

\author{
Arfin Sudirman ${ }^{1}$ \\ Achmad Fadly ${ }^{2}$ \\ ${ }^{1}$ Departemen Hubungan Internasional FISIP Universitas Padjadjaran, Indonesia \\ ${ }^{2}$ Departemen Hubungan Internasional FISIP Universitas Padjadjaran, Indonesia \\ Email: arfin.sudirman@unpad.ac.id
}

\begin{abstract}
ABSTRAK
Indonesia tengah membangun satu postur pertahanan yang menitik beratkan kepada soft power. Melalui peranan intelijen, reformasi sektor intelijen akan semakin berperan besar ketika berbicara mengenai kegiatan diplomasi pertahanan karena akan selalu berorientasi kepada kepentingan nasional. Reformasi sektor intelijen di tubuh pertahanan Indonesia kemudian dipertanyakan, disebabkan adanya tarik menarik kepentingan melalui eksistensi Bais TNI dengan badan intelijen pertahanan yang akan dibangun. Hasil yang dapat ditarik dalam artikel ini adalah reformasi sektor intelijen akan sangat kental dengan keputusan politik. Tarik menarik kepentingan antara Bais TNI dan BIP, mengenai kegiatan atase pertahanan, sangat mempengaruhi keputusan politik domestik Indonesia. Selain itu juga akan mempengaruhi dari anggaran pertahanan sebagai wujud dari reformasi sektor intelijen itu sendiri. Pada akhirnya juga keputusan politik dan menekan egosektoral di dalam tubuh kementerian pertahanan merupakan solusi terbaik sebagai wujud dari reformasi sektor intelijen di tubuh pertahanan Indonesia.
\end{abstract}

Kata Kunci: reformasi sektor intelijen; diplomasi pertahanan; atase pertahanan; kementerian pertahanan; Bais TNI.

\begin{abstract}
Indonesia is currently building a defence posture that focus on soft power. Through the role of intelligence, the inttelligence sector reform will take huge role in defence diplomacy as part of its orientation for national interest. However, there is growing concern in regards to intelligence sector reform that has been conducted by the Indonesia defence sector due to the fact that there is a conflict of interest concerning the existence of Bais TNI with the creation of the new Defence Intelligence Agency. The result that can be drawn from this article is that intelligence sector reform is highly dominated by political decision. The conflict of interest between Bais TNI and Defence Intelligence Agency on the activities of defence attaché will greatly affect upon political decision. Furthermore, it will also affect the budgeting aspect as a result of intelligence sector reform. In the end, political will and an effort to reduce the egosectoral inside the Indonesian Defense Ministry can be a solution for defense intelligence sector reform.
\end{abstract}

Keyword: intelligence sector reform, defence diplomacy, defence attache, Defense Ministry, Bais TNI. 


\section{PENDAHULUAN}

Perkembangan reformasi sektor keamanan di Indonesia saat ini merupakan salah satu diskursus yang selalu menarik untuk dibahas dikarenakan sifat alamiah dari ancaman dan keamanan yang dinamis. Sehingga pembahasan ini akan selalu diwarnai oleh pro dan kontra. Salah satu aspek yang menyebabkan hal ini adalah besarnya alokasi anggaran untuk meyakinkan bahwa Indonesia bebas dari ancaman dan ketakutan yang bersifat multidimensi dan terkadang subjektif sehingga rentan disalahgunakan oleh pemegang kebijakan.

Sebagai contohnya pada tahun 2015, pemerintah pusat mengalokasikan anggaran pertahanan sebesar Rp. 102,3 triliun setelah perubahan APBNP 2015 (Setuningsih, 2015). Perubahan anggaran pertahanan di tahun 2015 tersebut didominasi oleh pembelian alat utama sistem persenjataan (Alutsista) yang memiliki target untuk mengejar Minimum Essential Force 2024 (MEF 2024). Namun demikian, apabila berkaca kepada rencana strategis (renstra) Indonesia, 2015 merupakan tahun berjalannya renstra 2. Dimana dalam renstra tersebut akan didominasi oleh modernisasi alutsista serta kemandirian dalam Industri Pertahanan. Apabila melihat lebih dalam, total alokasi anggaran tersebut lebih dari $60 \%$ untuk pembelian alutsista dan sisanya akan diarahkan kepada belanja modal serta belanja pegawai (Setuningsih, 2015). Sehingga pertahanan yang bersifat tangible tersebut diharapkan dapat mengurangi tingkat ketidakpastian (uncertainty) untuk menghadirkan rasa keamanan (security) untuk menjaga kedaulatan negara dan masyarakat Indonesia.

Dengan adanya alokasi anggaran APBN tersebut, kehadiran keamanan memang dapat dirasakan namun masih bersifat semu dan belum menjadi jaminan pasti untuk meniadakan ancaman yang bersifat multidimensional dan transnasional. Sektor Pertahanan suatu negara dapat dikategorikan sebagai public goods, dimana hampir keseluruhan anggaran pertahanan harus dialokasikan dari APBN karena penggunaannya adalah untuk kepentingan negara dalam tugasnya menjaga kedaulatan negara, bukan untuk profit taking. Tidak menutup kemungkinan kekurangan anggaran ini ditutup dari pemasukan lainnya seperti pinjaman dalam negeri maupun luar negeri.

Menurut Undang-Undang no. 17 tahun 2003 tentang Keuangan Negara, pasal 11 ayat 5 (a) yang mengatur tentang belanja Pemerintah Pusat menurut fungsinya, dan pertahanan menjadi salah satu fungsi dari tugas dari Pemerintah Pusat. Kemudian fungsi dari pertahanan disini memang sepenuhnya tugas dari pemerintah pusat, dimana alokasi pertahanan sebagai penyelenggaraan keamanan tersebut. Peran dari 
anggaran disini akan menjadi dinamisator dalam penyelenggaraan pertahanan. Disinilah peranan pemerintah yang sangat intensif untuk menentukan arah kebijakan anggaran dan pertahanan dengan memasukkan pertimbangan kondisi negara, lingkungan strategis baik domestik maupun internasional serta daya serap anggaran nasional tersebut.

\section{PEMBAHASAN}

\section{Kompleksitas Ancaman} Kawasan Asia Tenggara

Dapat dipahami bahwa Indonesia merupakan negara maritim, dimana lebih dari 5,9 juta kilometer persegi merupakan daerah laut serta lebih dari 17.499 ribu pulau yang mengisinya (Marsetio, 2016: 3). Jumlah tersebut mengharuskan Indonesia untuk meningkatkan pertahanannya, baik dari segi kemaritiman ataupun daratan. Geoculture mindset yang terbangun di kalangan masyarakat Indonesia saat ini masih didominasi oleh kegiatan pertahanan yang bersifat land-centric atau continental. Pada dasarnya, dengan adanya fakta Indonesia sebagai archipelagic state yang diakui oleh Hukum Laut Internasional (UNCLOS), sistem dan strategi pertahanan Indonesia perlu dirubah sedemikian rupa. Anggaran pertahanan kemudian didasari oleh kepentingan dan keperluannya (Yusgiantoro, 2014: 7). Sehingga eksistensi dari Indonesia sebagai negara maritim perlu ditonjolkan ketimbang land atau continentalcentric sebagai dasar strategi pertahanan Indonesia.

Melihat kondisi geografis Indonesia tersebut, kebijakan yang dikembangkan oleh Presiden Jokowi dengan dalilnya 'Poros Maritim Dunia' seolah mendukung eksistensi Indonesia sebagai negara maritim. Namun demikian, dengan adanya perubahan lingkungan strategis baik dari domestik, regional maupun internasional sangat mempengaruhi dari sifat ancaman yang dihadapi serta kebijakan yang dihasilkan. Pada tahun 2015, Indonesia tengah dihadapi dengan meningkatnya ketegangan akibat sengketa Laut Tiongkok Selatan (LTS) antara Tiongkok dengan beberapa negara anggota ASEAN. Selain itu juga Menteri Pertahanan Ryamizard menjelaskan bahwa masalah terorisme dan radikalisme masih merupakan ancaman nyata di kawasan Asia Tenggara khususnya di Indonesia (Wahyuni, 2015). Merujuk kepada buku putih pertahanan Indonesia tahun 2015, ancaman nyata didominasi oleh ancamanancaman nir-militer dibandingkan dengan ancaman militer suatu negara. Perubahan tren ancaman disini semakin kontemporer karena eskalasi 'dunia tanpa batas' semakin nyata. Dengan kata lain, peranan informasi dan teknologi menjadi konkrit dibandingkan dengan 
ancaman militer berdimensi tradisional lainnya.

Sebagai contohnya adalah ancaman jaringan terorisme internasional yang masih menggunakan media informasi dan teknologi berupa internet dalam melakukan operasionalisasi kegiatannya mulai dari penyebaran ideologi radikal, perekrutan hingga teknik pembuatan bom. Fakta tersebut menunjukkan bahwa dominasi sektor pertahanan dalam penggunaan Alutsista kembali kepada pengembangan kompetensi Sumber Daya Manusianya (SDM) agar selalu up-to-date mengejar kecanggihan teknologi informasi. Selain itu, upaya lain yang harus diupayakan adalah meningkatkan peran intelijen pertahanan sebagai aktor utama. Sebagai contohnya, Amerika Serikat (AS) menggunakan strategi DIME (Diplomacy, Information, Military and Economy) sebagai unit kerja dalam mempertahankan negaranya (America, 2008). Di era globalisasi saat ini, informasi menjadi 'komoditas' tersendiri dalam melancarkan kebijakan-kebijakan yang efisien. Informasi yang dimaksud disini adalah bagaimana memaksimalkan kegiatan negara melalui peran intelijen untuk memberikan informasi yang bersifat early warning system dan velox et exatus (cepat dan tepat).

Jika melihat kondisi ancaman pertahanan kontemporer saat ini,
Indonesia tengah menghadapi kegiatan-kegiatan militer negara lain terutama akibat ketegangan di LTS tetapi pada saat yang bersamaan, Indonesia berusaha agar terhindar dari segala bentuk ancaman tersebut. Keamanan maritim Indonesia saat ini terkadang masih rentan terhadap ancaman transnasional berdimensi kriminal, dilihat dari maraknya illegal fishing diperbatasan laut utara Indonesia, penyelundupan manusia kerap terjadi, hingga mobilitas kejahatan-kejahatan sudah lintas batas negara. Dengan demikian eksistensi dari peranan intelijen perlu diperkuat agar deteksi dini dan pencegahan dini dari ancaman tersebut dapat terlaksana. Perlunya memasukkan peran intelijen sebagai strategi kebijakan pertahanan dengan mempertimbangkan dimensi ancaman yang multidimensional perlu mulai berkembang untuk merespon perubahan lingkungan strategis regional dan internasional.

\section{Peran Intelijen Dalam Pertahanan Negara}

Menurut Ikrar Nusa Bakti (2011), intelijen dapat diartikan sebagai informasi atau pengetahuan, organisasi atau kegiatan. Pentingnya peran intelijen bagi Indonesia dapat terlihat dari bagaimana kebijakankebijakan strategis dari segi pertahanan dilahirkan. Dalam dokumen Kebijakan Penyelenggaraan Pertahanan Negara 2015-2019, menyebutkan bahwa 
Vol.4, No.1, April 2018

bentuk pembinaan kemampuan dalam pembangunan Postur Pertahanan Negara adalah meningkatkan kemampuan intelijen mencakup kemampuan dalam menghadapi sifat, dimensi dan spektrum ancaman. Bahkan lebih spesifik lagi, Dokumen Kebijakan Penyelenggaraan Pertahanan Negara 2015-2019 menyebutkan bahwa Penguatan Kapasitas Intelijen dan Kontra Intelijen.

Penguatan kapasitas intelijen dan kontra intelijen untuk pertahanan negara yang diarahkan pada: (1) Peningkatan deteksi dan cegah dini, cipta opini dan cipta kondisi dengan kegiatan penggalangan melibatkan instansi terkait dan peran aktif seluruh tokoh yang ada di masyarakat. (2) Peningkatan tata kelola dan koordinasi serta pertukaran informasi sehingga tercipta interoperabilitas antar institusi intelijen baik militer maupun nonmiliter di pusat maupun daerah yang dikoordinasikan oleh Badan Intelijen Negara. (3) Peningkatan infrastruktur dan modernisasi alat penunjang kerja dan material khusus intelijen dengan memanfatkan perkembangan teknologi.

Mendukung penguatan intelijen melalui peningkatan sistem informasi pertahanan negara (Sisinfohanneg) berbasis pertahanan siber dengan memanfaatkan teknologi satelit. (5) Peningkatan profesionalisme Sumber Daya Manusia (SDM) dalam pengamanan informasi rahasia negara dengan melakukan pembinaan kesadaran intelijen serta perumusan regulasi di bidang intelijen sebagai pedoman dalam pelaksanaan intelijen negara.

Melalui kelima poin di atas, terciptanya interoperabilitas antar institusi intelijen menjadi hal yang menarik dengan melihat kondisi Indonesia di tahun 2016 ketika Kementerian Pertahanan ingin membentuk satu badan tersendiri yang menangani kegiatan intelijen pertahanan, Badan Intelijen Pertahanan atau BIP.

Perdebatannya pun bermunculan, baik dari kalangan akademisi pertahanan dan keamanan maupun masyarakat secara luas. Pada awalnya kegiatan intelijen tersebut dipegang oleh Badan intelijen Strategis TNI atau Bais TNI. Dimana memanfaatkan secara penuh kegiatan intelijen sebagai kegiatan dalam mendapatkan infromasi mengenai pertahanan dan keamanan negara Indonesia. Kemudian permasalahannya muncul ketika Bais TNI terjadi keterputusan komunikasi antar lembaga yang seharusnya menjadi naungan markas Besar TNI tersebut. Absennya koordinasi menjadi penyebab utama dan menjadi alasan utama bagi Kemhan untuk membentuk BIP (Kusumadewi, 2016). Mantan kepala Bais periode 2011-2013, Laksda TNI AL (Purn) Soleman B. Ponto menilai bahwa kehadiran BIP yang sedang dibentuk Kemhan belum sepenuhnya 
dibutuhkan. Dilain sisi perlu adanya perluasan kinerja Bais TNI dibandingkan dengan pembentukan badan baru tersebut. Dalam laporannya juga, Laksda TNI AL (Purn) Soleman B. Ponto mengatakan bahwa kehadiran BIP akan memboroskan anggaran negara (Kusumadewi, 2016).

Dilain sisi, menurut mantan

Rektor Universitas Pertahanan, Letjen (Purn) Syarifudin Tippe menyebutkan bahwa kehadiran BIP akan mencoba untuk mengatasi segala ancaman yang mulai berkembang, baik militer maupun nir-militer. Selanjutnya perbedaan pendapat ketika Laksda TNI AL (Purn) Soleman B. Ponto mengatakan bahwa ancaman nirmiliter menjadi domain Badan intelijen Negara (BIN) sedangkan ancaman militer menjadi domain Bais TNI. Yang menjadi permasalahan disini adalah bagimana kegiatan intelijen ini terkoordinasi dengan mantap, karena akan menjadi tumpang tindih tugas pokok antar lembaga. Arah dari kegiatan untuk menhadirkan BIP ini akan menjadi pertimbangan tersendiri terhadap efisiensi koordinasi antar lembaga intelijen. Karena pada dasarnya jalur koordinasi ini akan menghambat kegiatan pencarian informasi yang berdampak kepada pengambilan kebijakan pertahanan dalam menghadapi ancaman-ancaman saat ini. Melalui perubahan dan Peraturan Presiden nomor 80 tahun 2014 tentang perubahan struktur organisasi menyuratkan bahwa Badan Instalasi Strategis Nasional (Bainstranas) menjadi ujian terakhir dalam melihat konstelasi perubahan BIP terhadap kegiatan intelijen pertahanan saat ini. Refleksi Buku Putih Pertahanan Indonesia tahun 2015 memproyeksikan bahwa ancaman lima tahun kedepan akan didominasi oleh ancaman nir-militer. Maka, eksistensi Bainstranas yang menjadi garda intelijen utama dalam menghadapi ancaman-ancaman tersebut perlu dipertegas. Di sisi lain, mendeteksi ancaman yang tidak berdimensi militer tradisional akan dianggap bahwa kerja, tugas dan fungsi dari Bais TNI akan tidak bermanfaat. Dimensi dari kelembagaan tersebut akan dirasa tidak efisien ketika anggaran yang telah dialokasikan tidak akan menghasilan dari sesuatu yang sudah dibentuk dan dinyatakan, dalam hal ini adalah proyeksi ancaman tersebut.

Melihat adanya tumpang tindih koordinasi mengenai badan intelijen pertahanan tersebut, menariknya adalah ketika terjadi perubahan APBN 2016 ini, anggaran pertahanan ditingkatkan. Alokasi anggaran pertahanan naik sebesar Rp. 9.3 Triliun menjadi Rp. 108.7 Triliun, awalnya anggara pertahanan tidak sampai Rp. 100 Triliun (Primadhyta, 2016). Saat ini pemerintah Indonesia sedang berkonsentrasi kepada peningkatan 
pertahanan dan kemanan dalam menciptakan keamanan secara komprehensif. Namun, efektifitas dalam pengelolaan anggaran tersebut tidak jauh akan mengalir juga kepada pembentukan BIP atau sekarang kepada Bainstranas.

Selanjutnya yang menjadi permasalahan yang muncul pada artikel ini adalah penulis melihat bahwa momentum peningkatan anggaran pertahanan ketika terjadinya perdebatan keras terhadap pembentukan BIP tersebut. Reformasi sektor intelijen ini akan mempengaruh kebijakan-kebijakan operasional terhadap bentuk ancaman yang akan dihadapi oleh Indonesia. Selain itu juga efisiensi dalam sektor pertahanan ketika melihat tumpang tindihnya kinerja intelijen pertahanan antara Bais TNI dengan Bainstranas disini menjadi sorotan penting untuk dikaji. Hal tersebut penting karena beririsan langsung dengan aliran anggaran terhadap apa yang akan dihasilkan oleh lembaga-lembaga intelijen tersebut.

Sehingga rumusan masalah yang diangkat pada artikel ini adalah bagaimana reformasi sektor intelijen di tubuh sektor pertahanan dan di bawah otoritas politik Indonesia? Yang akan diteliti juga adalah proyeksi dari pengambilan kebijakan pertahanan ketika reformasi sektor intelijen pertahanan tersebut benarbenar terjadi di tubuh pertahanan Indonesia. Sehingga dalam penelitian ini akan menggunakan konsep yaitu reformasi sektor intelijen serta intelijen sebagai bagian dari instrumen diplomasi pertahanan di bawah keputusan politik.

\section{Reformasi Sektor Intelijen}

Dalam sebuah negara demokrasi, semua keputusan atau kebijakan merupakan kembali kepada otoritas sipil. Sehingga pada dasarnya intelijen merupakan tindakan otoritas negara untuk mendapatkan informasi untuk mengeluarkan kebijakan atau deteksi dini terhadap ancaman yang mengganggu keamanan nasional. Seperti yang telah disebutkan di atas, intelijen sendiri dapat diartikan sebagai organisasi, informasi ataupun tindakan (action). Namun dalam hal ini, intelijen yang akan diangkat adalah bagaimana reformasi sektor intelijen merupakan sebuah proses kebijakan serta tindakan stake holder melalui instrumen kebijakan tersebut. Andi Widjayanto menyebukan bahwa terdapat enam karakter utama uang harus dimiliki oleh sistem intelijen negara (Widjayanto dan Wardhani, 2008: 4) yaitu: pertama, Tunduk kepada otoritas politik, kedua, Terikat pada prinsip akuntabilitas hukum, politik, serta finansial, ketiga, Berkembang sebagai institusi profesional yang bersifat non-partisipan, dan/atau tidak untuk kepentingan pribadi, dan memiliki moralitas dan integritas 
Vol.4, No.1, April 2018

institusi yang kuat, keempat, Memiliki etos profesional yang terwujud dalam kode etik intelijen, kelima, Menjalankan fungsi spesifik, keenam, Memiliki kompetensikompetensi utama dan teknis yang spesifik sehingga dapat secara efektif menjadi bagian dari sistem peringatan dini dan pertahanan negara.

Melalui keenam karakter tersebut, peranan intelijen kemudian semakin mendalam. Pada awalnya bersifat pencairan informasi untuk bahan pertimbangan dalam mengeluarkan kebijakan, dan sekarang diharuskan mendapatkan tindakan deteksi dini (early warning) ketika mengganggu keamanan sebuah negara. Selain itu juga untuk menilai efektifitas reformasi sektor intelijen disini, yang akan menjadi bahan pertimbangan ialah posisi demokrasi dalam memaknai ancaman dan intelijen disini sebagai bentuk kewaspadaan ketika ancaman meningkat. Dalam bukunya Andi Widjayanto juga dijelaskan bahwa lembaga intelijen juga harus memiliki akuntabilitas politik untuk mencegah penggunaan lembaga intelijen untuk fungsi-fungsi yang tidak proporsional dan tidak profesional, yang pada akhirnya akan merusak kepercayaan publik pada lembaga intelijen, serta terjadinya pemusatan kekuasaan akibat dominasi terhadap lembaga intelijen di satu tangan atau institusi tertentu (Widjayanto dan Wardhani, 2008: 7).
Karena pada dasarnya peran intelijen merupakan public goods yang sepenuhnya merupakan anggaran dari pemerintah yang berasal dari pajak masyarakat. Sehingga perubahan yang mengarahkan kepada good governance and effectiveness harus ada dalam menilai sistem intelijen negara.

\section{Intelijen Sebagai Instrumen Diplomasi Pertahanan}

Dalam bukunya, Morghentau (1948: 17) menjelaskan bahwa konteks dari power akan bermuara kepada peranan diplomasi, militer dan ekonomi suatu negara. Instrumen diplomasi disini kemudian diterjemahkan oleh beberapa para peneliti bahwa kegiatan dari sebuah negara, di bawah naungan hukum internasional, untuk menggalangkan kegiatan intelijen secara legal. Bentuk dari kegiatan intelijen tersebut akan bermuara kepada keputusan politik luar negeri sebuah negara, karena landasan filosofis dari kegiatan tersebut juga bernafaskan kepentingan nasional. Sehingga kegiatan intelijen dapat dikatakan sebagai bagian dari kegiatan diplomasi di bawah payung hukum internasional.

Mengingat perubahan ancaman mulai bergeser ke konteks ancaman kontemporer, peranan intelijen-pun semakin berkembang. Salah satu tujuan menghadirkan diplomasi pertahanan juga adalah bagaimana peranan intelijen tersebut 
bertujuan untuk mengumpulkan informasi intelijen yang berkontribusi dalam suatu proses pengambilan kebijakan atau perencanaan militer. Diplomasi pertahanan sebagai alat kebijakan luar negeri untuk menggelar intelijen ini akan semakin diperjuangkan karena orientasi keamanan semakin dibutuhkan. Kemudian mendudukkan intelijen sebagai bagian dalam diplomasi pertahanan semakin jelas ketika mendudukkan kepentingan nasional, integrasi sektor domestik serta arah kebijakan luar negeri. Pada hakikatnya pagelaran intelijen di bawah otoritas politik serta mengendepankan eficiency and effectifness, and also transparancy, accountability. Keputusan dari politik serta insigh dari gejolak kepentingan nasional sangat mempengaruhi dari tindakan dan kegiatan intelijen, yang merupakan bagian dari instrumen diplomasi pertahanan (Supriyanto, 2014: 284-287).

Disinggung bahwa intelijen dikatakan sebagai bagian dari tujuan mengadakan alat diplomasi pertahanan dalam kebijakan luar negeri. Barkawi memahaminya sebagai kedudukkan diplomasi pertahanan tidak akan terlepas dari north-south relation, dimana keputusan politik negara bersifat top to down, atau hierarchy (Barkawi, 2011: 599). Dijelaskan pula bahwa regulasi lintas sektor terhadap diplomasi pertahanan sangat dibutuhkan, baik secara vertikal maupun horizontal. Keterkaitannya akan bermuara kepada peranan pemerintah untuk memaksimalkan kepentingan nasional sebuah negara. Diplomasi pertahanan disini juga menjadi representasi dari berbagai varian terhadap regulasi lintas sektor dan political-military organization.

Sebagai contoh ialah peranan dari atase pertahanan. Instrumen dari kegiatan tersebut merupakan defence diplomacy activities, karena salah satu tujuannya ialah meningkatkan CBMs terhadap negara tertuju (Cottey dan Forster, 2004: 17). Peranan intelijen disini juga akan turut hadir, disamping kegiatan atase pertahanan yang bersifat tradisional. Kemudian tumpang tindih dari pagelaran kegiatan atase pertahanan ini menjadi sangat kental ketika integrasi antara political institution tidak begitu kuat, bahkan cenderung memunculkan egosektoral antar lembaga. Dalam konteks ini adalah antara institusi TNI sebagai alat negara dan kementerian pertahanan yang merupakan lembaga strategis di bawah otoritas presiden.

\section{Kontradiksi BAIS TNI dengan BIP \\ Perdebatan mengenai} Kemhan yang berkeinginan untuk membentuk badan tersendiri mengenai intelijen pertahanan. Perdebatannya yang kemudian bermunculan antara pro dan kontra terhadap kebijakan Kemhan tersebut. 
Karena dilain sisi pembentukan BIP itu sendiri merupakan bentuk pemborosan dari anggaran. Akan tetapi yang menyepakati dengan pembentukan BIP merupakan maninfesto dari wacana yang dikeluarkan oleh Presiden Susilo Bambang Yudhoyono (Kusumadewi, 2016) yang membentuk Badan Instalasi Strategis Nasional (Bainstranas) di komplek Indonesia Peace and Security Center. Bainstranas itu sendiri menjadi cikal bakal dari BIP yang dimaksudkan oleh Kemhan itu sendiri.

Perdebatan yang pertama ialah mengenai tumpang tindih peran intelijen dengan badan lain yang telah ada. Mengutip dari pendapat mantan kepala Bais periode 20112013, Laksda TNI AL (Purn) Soleman B. Ponto mengatakan bahwa tumpang tindih peran intelijen akan terjadi, bukan hanya antara Bais TNI melainkan dengan Badan Intelijen Negara (BIN) (Kusumadewi, 2016). Dasar dari argumen Ponto tersebut terbilang masuk akal karena peranan dari BIN itu sendiri sebagai lembaga koordinasi juga bagaimana menciptakan deteksi dini dari segala bentuk yang mengancam keamanan nasional. Hal tersebut juga termahtub dalam Undang-undang Republik Indonesia no. 17 tahun 2011 mengenai Intelijen Negara mengenai fungsi intelijen di pasal 6 ayat 1 menyebutkan bahwa intelijen negara menyelenggarakan

fugsi penyeledikan, pengamanan dan penggalangan (Kusumadewi, 2016).

Namun dalam amanat undang-undang mengenai tugas dari BIN tersebut tidak menyinggung mengenai peranan BIN dalam konteks pertahanan dan ancaman. Sedangkan tugas dari Bais itu sendiri merupakan badan tersendiri dibawah koordinasi Markas Besar TNI dalam menyusun intelijen militer ketika menghadapi situasi yang harus menggunakan kekuatan militer.

Selanjutnya, beberapa yang pro dalam pembentukan badan tersebut antara lain Menteri Pertahanan Ryamizard Ryacudu, Letjen (Purn) Syarifudin Tippe, serta Kepala Bainstranas Kemhan Mayjen Paryanto. Sebagian besar dari mereka memahami bahwa dimensi dari ancaman sudah semakin luas dan mendalam. Ancaman nir-militer mulai mendominasi dibandingkan ancaman militer, sehingga perlu dibentuknya satu badan yang bertujuan untuk merumuskan kebijakan pertahanan (Paskali, 2016). Apabila berkaca dalam undang-undang no. 17 tahun 2011 mengenai intelijen negara, pasal 7 menyebutkan bahwa salah satu ruang lingkup intelijen negara adalah intelijen pertahanan dan/atau militer. Amanat undang-undang jelas menyebutkan bahwa ruang lingkup intelijen tersebut termasuk unsur pertahanan. Disebutkan bahwa BIP ini bukan untuk mengambil alih tugas fungsi dan tugas dari Bais TNI, 
BIN dan lainnya melainkan bagian dari komuitas intelijen di bawah koordinasi BIN dengan fokus pada persoalan pertahanan negara (Kusumadewi 2016). Hal ini sudah sesuai dengan undang-undang no. 17 tahun 2011 pasal 38 yang menyebutkan bahwa BIN berkedudukan sebagai koordinator peyelenggaraan intelijen negara.

Berkaca kepada reformasi sektor intelijen, bagimana peranan intelijen negara terhindar dari penunggangan kepentingan lembaga atau pribadi serta menjunjung tinggi nilai-nilai transparansi dan akuntabilitas. Untuk menciptkan hal tersebut, perlu adanya transparansi anggaran intelijen negara. Namun demikian, eksistensi peranan intelijen yang dirasa perlu classified, menjadi pertimbangan tersendiri. Ketika peranan intelijen terbuka pada segala hal, akan menimbulkan pelemahan informasi dan distorsi terhadap informasi tidak akan terhindari. Sehingga reformasi sektor intelijen yang terjadi di momentum 2016 ini menjadi menarik karena mempengaruhi dari perubahan anggaran yang didominasi oleh pertahanan dan keamanan (Primadhyta, 2016). Apabila merefleksikan dengan kebijakan strategis pertahanan Indonesia, Presiden Joko Widodo saat ini memang sedang membangun postur pertahanan yang sangat komprehensif. Hal tersebut dinilai sebagai tindakan dukungan untuk menciptakan Indonesia sebagai poros maritim dunia.

Perkembangannya sejauh ini adalah BIP ini ditunjuk dalam rangka mempertajam analisa strategis dalam perkembangan lingkungan global, nasional maupun regional dalam memprediksikan dan merumuskan ancaman dengan menyusun strategi pertahanan yang komprehensif (Ramadhan, 2016). Bais TNI berbicara mengenai pergerakan lawan terhadap kegiatan militer ketika Indonesia dalam keadaan darurat, sedangkan BIP itu sendiri langsung berkoordinasi dengan Kemhan sebagai salah satu alat yang dapat mempengaruhi kebijakan operasional dalam menghadapi spektrum ancaman yang semakin kontemporer. Kehadiran BIP itu sendiri menunjukan sebagai amanat undang-undang no. 17 tahun 2011 serta maninfesto dari undang-undang no. 3 tahun 2002. Pada akhirnya dalam perspektif ini dapat dikatakan bahwa eksistensi BIP dirasa sangat wajar. Mengingat tingkat kebutuhan strategis dalam pengambilan kebijakan pertahanan, berbeda dengan kegiatan Bais TNI yang bersifat taktis dan operasional.

Ketika meninggalkan sudut pandang tersebut dan membangun sudut pandang baru, BIP dirasa belum dibutuhkan mengingat Bais TNI itu sendiri dapat diperluas rana kinerjanya. Dalam artian mengangkat Bais TNI sebagai unit baru tersendiri bagi Kemhan untuk memenuhi 
kebutuhan intelijen pertahanan itu sendiri. Meruhuk dari pasal $11 \mathrm{di}$ undang-undang no. 17 tahun 2011 menilai bahwa pemerintah sebetulnya tidak membutuhkan badan intelijen baru, karena Kemhan dapat menerima laporan dan informasi intelijen dari Bais (Lumbanrau, 2016). Sehingga dengan kata lain bahwa sedang diusahakan untuk memaksimalkan sesuatu yang telah ada, dalam hal ini ialah Bais TNI, dan diberikan wewenang baru dan luas sesuai dengan kebutuhan. Karena hal ini akan bersinggungan langsung dengan alokasi anggaran yang telah disepakati ole keputusan politik, yaitu Dewan Perwakilan rakyat yang menjalankan fungsinya sebagai badan penganggaran. Hal ini sebagai wujud dari reformasi sektor intelijen dengan mendudukkan demokrasi sebagai 'nafas' negara Indonesia.

Pada akhirnya, momentum perubahan APBN 2016 dirasa menjawab perdebatan tersebut. Peningkatan anggaran tersebut memang bentuk nyata dari Presiden Joko Widodo untuk meningkatkan keamanan baik dalam maupun luar negeri sebagai wujud dari nawa citanya. Wujud dari peningkatan pertahanan, dalam hal ini intelijen, seharusnya berbanding lurus dengan pembangunan infrastruktur (Widjayanto dan Wardhani, 2008: 62). Di tahun 2016 ini, ekonomi global sedang mengalami kemajuan dan Indonesia memanfaatkan momentum itu untuk meningkatkan anggaran pertahanan tersebut. Disebutkan bahwa peningkatan anggaran pertahanan dan keamanan utamanya untuk membeli alat utama sistem senjata (Primadhyta, 2016). Namun dilain sisi Kepala Bainstranas Mayjen Paryanto menyebutkan bahwa BIP sebenarnya tinggal menunggu Perpres, dan fungsi intelijennya sejauh ini telah dibebankan di Bainstranas (Kusumadewi, 2016). Selama hal tersebut mampu menjembatani kepentngan Indonesia ketika menghadapi ancaman nonmiliter, BIP dirasa cukup mampu mengemban tugasnya dan tentu saja tetap di bawah koordinasi BIN.

\section{SIMPULAN}

Kesimpulan yang dapat ditarik dalam artikel ini adalah reformasi sektor intelijen sangat mempengaruhi terhadap kegiatan diplomasi pertahanan. Pergejolakan politik domestik terkait antara Bais TNI dan pembentukan BIP sebagai badan baru sangat kental karena akan juga berbicara terhadap orientasi kepentingan nasional serta efektifitas dan transparansi di bawah otoritas politik. Kebingungan mengenai kegiatan diplomasi pertahanan yang diperankan oleh atase pertahanan juga merupakan bagian dari pernaan intelijen oleh Indonesia. Ketika tubuh sektor intelijen pertahanan saja mengalami tarik-menarik kepentingan, reformasi sektor 
intelijen tersebut tidak akan berjalan secara komprehensif. Alasan lainnya juga akan mempengaruhi tingkat efisiensi anggaran pertahanan itu sendiri sebagai salah satu wujud dari reformasi sektor intelijen. Pada akhirnya untuk menjawab pertanyaan penelitian di atas adalah semua akan dipengaruhi oleh political will serta menekan egosektoral di tubuh kementerian pertahanan itu sendiri. Karena pada akhirnya kebijakan luar negeri akan dilhat sebagai satu kesatuan yang dikeluarkan oleh Indonesia, bukan satu lembaga saja.

\section{DAFTAR PUSTAKA}

\section{BUKU}

Chutter, D. (2011). Governing \& Managing the Defense Sector. Pretoria: Institute for Security Studies.

Cottey, A., \& Forster, A. (2004).

Reshaping Defence

Diplomacy: New Roles for Military Coorporation and Assistance. London: Oxford University Press.

Supriyanto, M. (2014). Tentang Ilmu

Pertahanan. Jakarta: Yayasan

Pustaka Obor Indonesia.

Widjayanto, A., \& Wardhani, A.

(2008). Hubungan Intelijen -

Negara 1945 - 2004. Jakarta:

Pacivis.

Yusgiantoro, P. (2014). Ekonomi

Pertahanan: Teori dan

Praktik. Jakarta: PT.

Gramedia Pustaka Utama.
JURNAL

Barkawi, T. (2011). Defence Diplomacy in North-South Relations. International Journal.

ARTIKEL DALAM WEBSITE

America, M. o. (2008). Defense Strategic Review. Ministry of Defense.

Ariyanti, F. (2016, June 21). Ini Postur Sementara Revisi $A P B N$ 2016. Diambil kembali dari Liputan 6: http://bisnis.liputan6.com/rea d/2536679/ini-postursementara-revisi-apbn-2016

Indonesia. (2011). Undang-Undang RI No. 17 tahun 2011 mengenai Intelijen Negara. Diambil kembali dari http://www.icnl.org/research/l ibrary/files/Indonesia/UU.pdf

Keuangan, K. (2016, June). Kementerian Keuangan. Diambil kembali dari Kementerian Keuangan: http://www.anggaran.depkeu. go.id/dja/acontent/buku\%20d asar\%20penyusunan\%20APB N.pdf

Kusumadewi, A. (2016, June 10). Badan Intelijen Pertahanan Tinggal Tunggu Peraturan Presiden. Diambil kembali dari CNN Indonesia: http://www.cnnindonesia.com /nasional/2016061017355720-137296/badan-intelijenpertahanan-tinggal-tungguperaturan-presiden/ 
Kusumadewi, A. (2016, June 15). Badan Intelijen Strategis TNI dan Kemhan Putus Hubungan. Diambil kembali dari CNN Indonesia: http://www.cnnindonesia.com /nasional/20160615083358 20-138240/badan-intelijenstrategis-tni-dan-kemhanputus-hubungan/

Kusumadewi, A. (2016, June 10). Bainstranas, Benih Badan Intelijen Pertahanan. Diambil kembali dari CNN Indonesia: http://www.cnnindonesia.com /nasional/2016061014115420-137205/bainstranas-benihbadan-intelijen-pertahanan/

Lumbanrau, R. E. (2016, June 10). Badan Intel kemhan Diklaim Jadi Benteng Ancaman Nonmiliter. Diambil kembali dari CNN Indonesia: http://www.cnnindonesia.com /nasional/2016061011071320-137139/badan-intelkemhan-diklaim-jadibenteng-ancaman-nonmiliter/ Paskali, Y. (2016, June 16). Begini Alasan Kemhan Bentuk Badan Intelijen Pertahanan. Diambil kembali dari Tempo.co: https://m.tempo.co/read/news /2016/06/16/078780403/begi ni-alasan-kemhan-bentukbadan-intelijen-pertahanan

Primadhyta, S. (2016, June 29). Pertahanan dan Keamanan
Jadi Fokus belanja K/L APBN-P 2016. Diambil kembali dari CNN Indonesia: http://www.cnnindonesia.com lekonomi/2016062918563578-141908/pertahanan-dankeamanan-jadi-fokus-belanjak-l-apbn-p-2016/

Ramadhan, A. (2016, Maret 4). Kemhan akan bentuk Badan Intelijen Pertahanan. Diambil kembali dari Antara Newa: http://www.antaranews.com/b erita/548528/kemhan-akanbentuk-badan-intelijenpertahanan

Rusmana, Y. (2016, January 3). Indonesian GDP Growth Misses Target in 2015, Ministry Reports. Diambil kembali dari Bloomberg: http://www.bloomberg.com/n ews/articles/2016-0103/indonesian-gdp-growthmisses-target-in-2015ministry-reports

Seputar Indonesia, 29 Maret 2011, Intel Juga Manusia, hlm. 7.

Setiaji, H. (2016, March 15). World Bank cuts Indonesia 2016 growth forecast to 5,1 percent, sees revenue miss. Diambil kembali dari Reuters: http://www.reuters.com/articl e/us-indonesia-economy-gdpidUSKCNOWHODN

Setuningsih, N. (2015, July 7). Berita Satu. Diambil kembali dari 
Vol.4, No.1, April 2018

Berita

Satu:

http://www.beritasatu.com/na

sional/288971-anggaran-naik-

kemhan-pastikan-beli-

alutsista-baru.html

Wahyuni, T. (2015, Agustus 1). Menteri Pertahanan Bicara Soal Banyak Ancaman Bagi Indonesia. Diambil kembali dari $\mathrm{CNN}$ Indonesia: http://www.cnnindonesia.com /politik/20150731140129-3269330/menteri-pertahananbicara-soal-banyak-ancamanbagi-indonesia/

\section{MAKALAH SEMINAR}

Marsetio, L. T. Diplomasi Maritim. Diplomasi Maritim dalam Mendukung Poros Maritim Dunia. Makalah disajkan dalam Kuliah Umum. Unhan, Bogor, 2016. 